\title{
UPAYA MENINGKATKAN HASIL BELAJAR MATEMATIKA DENGAN ALAT PERAGA BATANG NAPIER
}

\author{
Nur Waqi'ah \\ Guru SDN Tampungrejo Kec. Puri Kab. Mojokerto \\ Email: nurwaqiah1961@gmail.com
}

\begin{abstract}
Abstrak : Penelitian ini bertujuan untuk meningkatkan aktivitas dan hasil belajar perkalian bilangan bulat melalui penerapan batang Napier di SDN Tampungrejo. Subyek penelitian berjumlah 27 siswa yang terdiri dari 12 siswa laki-laki dan 15 siswa perempuan. Pengambilan data dilakukan dengan observasi aktivitas siswa dan tes pada setiap akhir siklus. Prosedur penelitian ini meliputi : penyusunan rencana, tindakan,observasi, dan refleksi. Pada siklus III, ketuntasan klasikal yang dicapai siswa sebesar 92,59\% dengan rata-rata nilai 87,22.
\end{abstract}

Kata Kunci: hasil belajar, matematika, batang napier

Berdasarkan Undang-undang No. 20 Tahun 2003 tentang Sistem Pendidikan Nasional pasal 3 menyebutkan bahwa pendidikan nasional berfungsi mengembangkan kemampuan dan membentuk watak serta peradapan bangsa yang bermartabat dalam rangka mencerdaskan kehidupan bangsa, bertujuan untuk berkembangnya potensi siswa agar menjadi manusia yang beriman dan bertakwa kepada Tuhan Yang Maha Esa, berakhlak mulia, sehat, berilmu, cakap, kreatif, mandiri, dan menjadi warga negara yang demokratis dan bertanggung jawab.

Guru atau pengajar adalah salah satu komponen yang penting yang menentukan keberhasilan siswa dalam belajar mengajar. Seorang guru dituntut kreatif, inovatif dalam menciptakan suasana pembelajaran. Siswa jangan diajarkan menghafal teori-teori, konsep-konsep, fakta dan rumus-rumus dengan metode ceramah sehingga membuat siswa tidak termotivasi dalam mengikuti pembelajaran. Memberikan pengalaman langsung dengan mengaitkan apa yang dipelajari dengan kontek yang nyata akan lebih bermakna bagi siswa.

Sebagai penyelenggara pendidikan dasar, Sekolah Dasar mempunyai peranan penting untuk mempersiapkan siswa dengan memperkenalkan ilmu pengetahuan dasar, sebagai bekal siswa untuk dapat melanjutkan kegiatan belajarnya pada lembaga pendidikan yang lebih tinggi. Peneliti adalah guru kelas di SDN Tampungrejo Puri Kabupaten Mojokerto. Berdasarkan hasil pembelajaran menunjukakan bahwa siswa kelas III sebagian belum mahir melakukan operasi perkalian. Berdasarkan data nilai, banyak siswa yang mendapat nilai di bawah KKM (di bawah 70). Karena kurang memperhatikan pembelajaran, sering ngobrol dengan teman atau justru bermain sendiri. Untuk mengatasi permasalahan tersebut perlu kiranya adanya pembelajaran yang bisa membuat siswa aktif. 
Pembelajaran yang aktif perlu dilakukan dengan menggunakan metode, model, strategi, dan alat peraga yang sesuai dengan materi belajar siswa, karena pembelajaran matematika yang dapat merangsang siswa untuk lebih mengetahui dan memotivasi siswa dalam belajar dan sekaligus dapat meningkatkan pemahaman siswa terhadap matematika sangat ditunggu baik oleh siswa maupun guru. Alat peraga adalah alat yang dapat diserap oleh mata dan telinga sebagai alat bantu dalam menciptakan proses belajar mengajar yang efektif. Dengan alat peraga perkembangan kognitif dan perolehan kecakapan intelektual siswa akan terjadi dengan menyeimbangkan antara apa yang mereka rasakan dan ketahui pada suatu sisi dengan apa yang mereka lihat suatu fenomena baru sebagai pengalaman atau persoalan. Dalam hal ini, pengetahuan siswa menciptakan pembelajaran yang menarik dengan memunculkan alat peraga sebagai alat bantu (Sudjana, 2010:99).

Menurut Piaget siswa sekolah dasar dalam usia 6 sampai 13 tahun masih berada dalam fase operasional kongkret. Kemampuan yang tampak pada fase ini adalah kemampuan dalam proses berfikir untuk mengoperasikan kaidah-kaidah logika, meskipun masih terikat dengan objek yang bersifat kongkret (Heruman, 2008:1). Oleh sebab itu peneliti ingin mencoba mengajar menggunakan alat peraga untuk memahami materi yang dianggap rumit bagi siswa. Fokus peneliti ini adalah meningkatkan hasil belajar matematika siswa dalam mengerjakan soal perkalian melalui alat peraga batang napier.

Batang Napier adalah suatu media dimana ide pemikirannya adalah mengubah proses yang kompleks yaitu perkalian dan pembagian menjadi penambahan dan pengurangan. Perkalian bilangan dengan menggunakan batang napier yaitu dengan menerjemahkan persoalan perkalian menjadi persoalan penjumlahan. Cara mengalikan bilangan dengan batang napier cukup mudah, yaitu hanya melihat bilangan yang akan dikalikan, kemudian menjumlahan diagonalnya. Sehingga diharapkan siswa tidak mengalami kesulitan lagi dalam memahami perkalian maupun pembagian. Yang pada akhirnya diharapkan hasil belajar siswa akan meningkat. Hal ini yang mendorong peneliti untuk menggunalkan Alat peraga batang Napier dalam upaya meningkatkan hasil Belajar Matematika Siswa Kelas III SDN Tampungrejo Puri Kabupaten Mojokerto Tahun Pelajaran 2013/2014”.

\section{METODE}

Jenis penelitian ini merupakan penelitian tindakan kelas (classroom action research). Tujuan utama dari penelitian tindakan ini adalah untuk meningkatkan hasil pembelajaran di kelas dimana guru secara penuh terlibat dalam penelitian. Penelitian tindakan kelas (PTK) merupakan salah satu alternatif yang dapat dilakukan untuk mengenal masalah-masalah yang dialami siswa dalam memahami konsep pada pembelajaran matematika dan untuk mengetahui usaha dalam mengatasinya. Jenis penelitian ini dilakukan secara kolaborasi antara kepala sekolah, pendidik, dan peneliti.

Pelaksanaan PTK dan pengumpulan data dilakukan dalam beberapa siklus, setiap siklus terdiri dari 4 langkah yaitu perencanaan (planning), tindakan (acting), pengamatan (observing) dan refleksi (reflecting). Perencanaan 
(Planning) pada langkah ini peneliti merencanakan perangkat pembelajaran dan instrumen peneliti yang akan digunakan pada saat penelitian yaitu : Rencana pelaksanaan pembelajaran (RPP), Buku materi pelajaran matematika untuk kelas $\mathrm{V}$, Instrumen pengamatan PBM dan Tes untuk mengetahui hasil belajar siswa. Tindakan (acting) tahap ini adalah pelaksanaan yang merupakan implementasi atau penerapan isi rancangan, tindakan yang dilakukan adalah pelaksanaan proses belajar mengajar dikelas yang mengacu pada RPP dengan penerapan metode pembelajaran menggunakan batang Napier.

Pengamatan (observing) observasi atau pengamatan dilakukan pada waktu tindakan sedang berlangsung, jadi keduanya berjalan dalam waktu yang sama. Peneliti menerapkan perangkat pembelajaran yang telah dibuat di kelas. Peneliti melakukan proses belajar mengajar di kelas dengan alat peraga batang Napier. Selama proses pembelajaran berlangsung, peneliti akan diamati oleh dua orang pengamat. Pengamat adalah guru matematika sekolah tersebut, yang akan mengamati kemampuan peneliti dalam mengelola pembelajaran dengan menggunakan alat peraga batang Napier.

Refleksi merupakan kajian terhadap hasil observasi proses belajar mengajar yang sudah berlangsung. Tahapan ini dimaksudkan untuk mengkaji secara menyeluruh tindakan yang telah dilakukan. Sehingga peneliti dapat mengetahui kelebihan dan kekurangannya pada saat mengajar dan peneliti dapat memperbaiki kekurangan dalam pelaksanaan tindakan sesuai hasil evaluasi untuk digunakan pada siklus selanjutnya. Melalui refleksi inilah peneliti akan menentukan keputusan untuk melakukan siklus lanjutan ataukah berhenti karena masalahnya telah dipecahkan.

\section{Tempat Penelitian}

Penelitian ini dilakukan di SDN Tampungrejo pada semester I tahun pelajaran 2013/2014. Subyek penelitian ini adalah siswa kelas III SDN Tampungrejo dengan jumlah siswa sebanyak 27 siswa.

\section{Waktu Penelitian}

Penentuan waktu penelitian mengacu pada kalender pendidikan sekolah dan jadwal pelajaran kelas III SDN Tampungrejo Puri yaitu pada semester gasal tahun 2013/2014. Penentuan waktu didasarkan karena PTK memerlukan beberapa siklus yang membutuhkan proses belajar mengajarkan yang efektif sehingga tidak menggangu waktu yang lain.

\section{Instrumen Penelitian}

Observasi adalah instrumen lain yang sering dijumpai dalam penelitian pendidikan. Instrumen observasi akan lebih efektif jika informasi yang hendak diambil berupa kondisi atau fakta alami, tingkah laku dan hasil kerja responden dalam situasi alami. Untuk memaksimalkan hasil observasi peneliti biasanya menggunakan alat bantu yang sesuai dengan kondisi lapangan. Diantaranya alat bantu observasi adalah buku catatan dan chek list.

Soal Tes, Dalam penelitian ini, tes yang digunakan adalah tes subjektif berbentuk essay (uraian). Tes uraian ini digunakan untuk mengetahui sejauh mana 
pemahaman siswa tentang materi operasi perkalian kelas III. Sebelum soal tes diberikan, terlebih dahulu peneliti menguji validitas dan reabilitas soal tes tersebut. Adapun uji validitas dan reabilitas sebagai berikut :

\section{Metode Pengumpulan Data}

Metode pengumpulan data digunakan untuk memperoleh data yang sesuai dengan masalah yang dihadapi dalam penelitian. Adapun metode pengumpulan data yang digunakan dalam penelitian ini adalah (1) metode tes dan (2) metode observasi.

Metode tes digunakan untuk memperoleh data tentang hasil belajar siswa pada materi operasi hitung setelah dilakukan pembelajaran dengan alat peraga batang Napier. Tes yang digunakan adalah tes formatif yang dilaksanakan setelah dilakukan pembelajaran dengan alat peraga batang Napier. Metode observasi digunakan untuk memperoleh data aktivitas siswa maupun aktivitas guru dalam proses belajar mengajar dengan penerapan alat peraga batang Napier yang berpedoman pada instrumen pengamatan.

\section{Teknik Analisis Data}

\section{Analisis data aktivitas belajar siswa}

Aktivitas belajar siswa dikatakan efektif apabila mencapai prosentase aktivitas belajar siswa $80 \%$ pada kategori aktif selama penerapan pembelajaran dengan menggunakan alat peraga berlangsung. Ketuntasan aktivitas belajar siswa dapat diketahui menggunakan rumus: keaktifan siswa = jumlah nilai yang diperoleh dibagi jumlah skor maksimal kali 100

\section{Analisis data hasil belajar siswa}

Ketuntasan hasil belajar siswa dapat diukur dengan menggunakan tes setelah tindakan. Hasil tes tersebut dianalisis untuk mengetahui ketuntasan hasil belajar. Adapun analisis data hasil belajar siswa pada penelitian ini meliputi, (1) Rata-rata hasil belajar siswa, (2) meningkat hasil belajar individu, (3) ketuntasan belajar klasikal.

Siswa dikatakan mengalami Meningkat hasil belajarnya secara individu jika hasil tes yang diperoleh memenuhi KKM yang telah ditetapkan oleh sekolahnya, tetapi jika siswa belum mencapai KKM yang telah ditetapkan maka siswa tersebut mengalami Menurun hasil belajarnya. Adapun standar KKM matematika pada kelas III SDN Tampungrejo Puri Kabupaten Mojokerto adalah 70. Ketuntasan hasil belajar klasikal dapat diperoleh apabila terdapat minimal 85\% dari jumlah siswa dikelas yang telah mencapai ketuntasan hasil belajar.

\section{HASIL DAN PEMBAHASAN}

\section{Aktivitas siswa}

Berdasarkan hasil analisis data didapat bahwa aktivitas siswa mengalami peningkatan dari siklus ke siklus yakni dari 67\% (cukup aktif) pada siklus I menjadi $73 \%$ pada siklus II dikategorikan cukup aktif dan $87 \%$ (aktif) pada siklus III. Beberapa hal yang penting adalah kemampuan guru dalam mendidik siswa, mengetahui perbedaan individu, serta dalam menciptakan suasana belajar yang 
aktif dan menyenangkan sangatlah penting. Dengan adanya pembelajaran menggunakan alat peraga membantu siswa untuk meningkatkan rasa keingintahuan mereka dan sikap kritis mereka, kesadaran dalam membentuk kelompok-kelompok belajar ditunjang dengan tugas. Sehingga pembelajaran lebih berarti dan menyenangkan. Selanjutnya siswa akan bekerja keras untuk mencapai tujuan pembelajaran, mereka menggunakan pengalaman dan pengetahuan untuk membangun pengetahuan yang baru.

Dapat dikatakan bahwa penerapan pembelajaran menggunakan alat peraga dapat meningkatkan aktivitas siswa kelas III SDN Tampungrejo Puri dalam pembelajaran materi Operasi perkalian. Aktivitas siswa pada siklus I, siklus II, dan siklus III dapat ditunjukan pada tabel dan diagram berikut:

Tabel 4.9. Analisa Aktivitas Belajar Siswa Siklus I, Siklus II dan Siklus III

\begin{tabular}{|c|c|c|c|c|}
\hline No & Nama & Siklus I & Siklus II & Siklus III \\
\hline 1 & Kurang aktif & 3 & 0 & 0 \\
\hline 2 & Cukup aktif & 21 & 15 & 2 \\
\hline 3 & Aktif & 3 & 12 & 25 \\
\hline
\end{tabular}

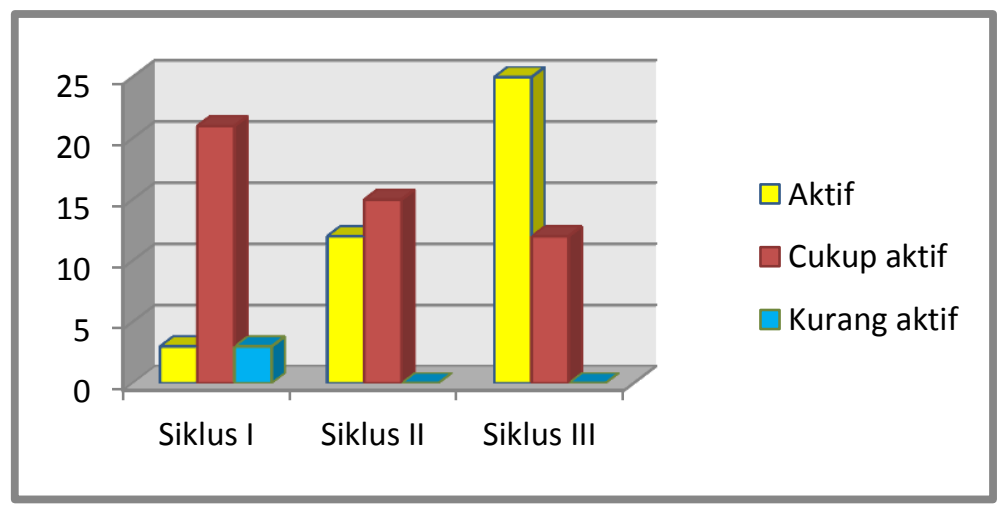

Gambar 1. Diagram aktivitas siswa siklus I, II, dan III

\section{HASIL BELAJAR SISWA}

Hasil belajar siswa pada siklus I dari 27 siswa terdapat 11 siswa yang hasil belajarnya meningkat dan terdapat 16 siswa yang hasil belajarnya menurun. Menurun hasil belajar siswa ini disebabkan mereka belum mencapai KKM yang telah ditetapkan. Dari jumlah siswa yang telah lulus atau mencapai nilai KKM yang sudah ditetapkan dapat dilihat bahwa peningkatan klasikal tercapai sebesar $40,74 \%$. Hasil belajar pada siklus I ini nilai rata-ratanya 62,78 hal ini disebabkan siswa belum terbiasa dalam pembelajaran menggunkan alat peraga. Namun demikian hasil belajar mereka sudah mengalami peningkatan dari hasil ulangan harian sebelum menerapkan pembelajaran menggunakan alat peraga. Hal ini mungkin mereka lebih sering belajar dengan menggunakan metode ceramah murni dari guru tanpa menggunakan media pembelajaran, apalagi menggunakan alat peraga. 
Pada siklus II hasil belajar sudah baik ada peningkatan hasil belajar secara individu dan juga secara klasikal, ada 9 siswa yang hasil belajarnya menurun, namun 18 siswa telah meningkat secara klasikal sudah mencapai $66,67 \%$ dengan rata-rata,74,26. Jika dibandingkan dengan hasil belajar pada siklus I, siklus II mengalami peningkatan secara klasikal yaitu sebesar 25,93\% dengan rata-rata meningkat sebesar 11,48.

Pada siklus III hasil belajar sudah sangat baik ada peningkatan hasil belajar secara individu dan juga secara klasikal, walaupun masih ada 3 siswa yang hasil belajarnya menurun, namun 25 siswa telah meningkat. Ketuntasan secara klasikal sudah meningkatan mencapai $92,59 \%$ dengan rata-rata 87,22. Jika dibandingkan dengan hasil belajar pada siklus II, siklus III mengalami peningkatan secara klasikal yaitu sebesar $25,92 \%$ dengan rata-rata meningkat sebesar 12,96 .

Hasil belajar yang meningkat pada siklus III ini menunjukkan bahwa penerapan pembelajaran menggunakan alat peraga dapat meningkatkan hasil belajar siswa kelas III SDN Tampungrejo Puri Kabupaten Mojokerto. Nilai meningkat siswa pada siklus I, II, dan III dapat ditunjukan pada tabel dan diagram berikut:

Tabel 6. Analisis Hasil Belajar Siswa Siklus I, II dan III

\begin{tabular}{|c|l|c|c|c|}
\hline No & \multicolumn{1}{|c|}{ Uraian } & Siklus I & Siklus II & Siklus III \\
\hline 1 & Nilai tertinggi & 90 & 95 & 100 \\
\hline 2 & Nilai terendah & 40 & 55 & 70 \\
\hline 3 & Nilai rata-rata & 62,78 & 74,26 & 87,22 \\
\hline 4 & Jumlah siswa & 27 & 27 & 27 \\
\hline 5 & Jumlah siswa yang Memenuhi KKM & 11 & 18 & 24 \\
\hline 6 & Prosentase Ketuntasan Klasikal & $40,74 \%$ & $66,67 \%$ & $92,59 \%$ \\
\hline
\end{tabular}

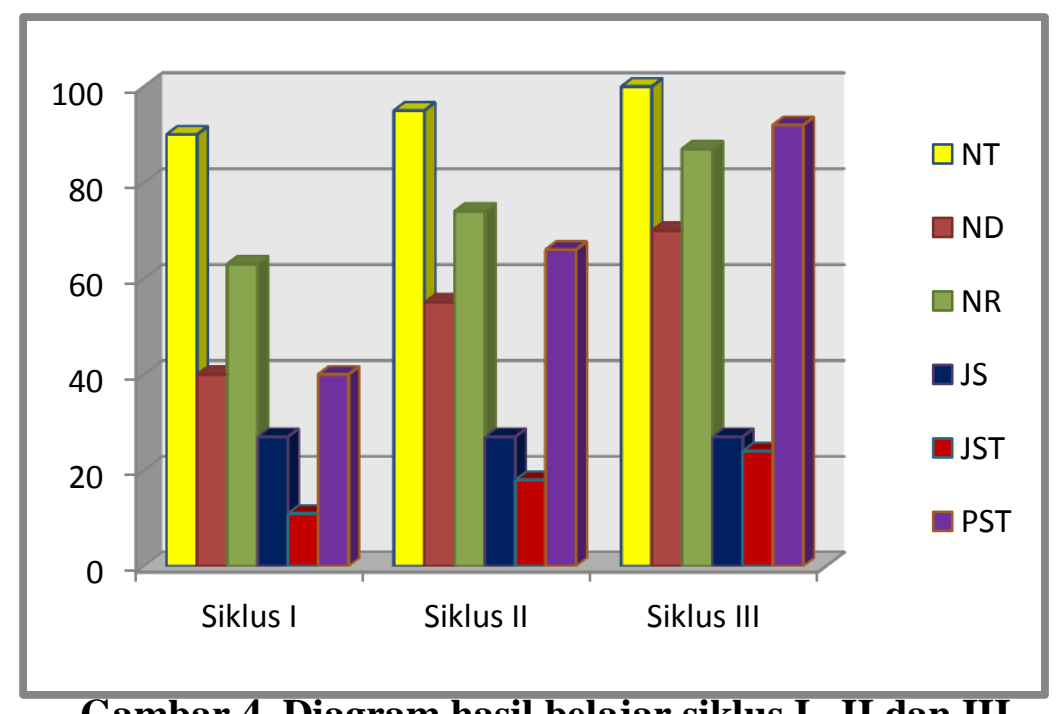

Gambar 4. Diagram hasil belajar siklus I, II dan III 


\section{KESIMPULAN}

Berdasarkan hasil penelitian yang telah diuraikan dapat disimpulkan sebagai berikut: (1) Upaya meningkatkan aktivitas siswa dengan alat peraga batang napier pada materi operasi perkalian telah berhasil dicapai. Hal ini dapat dilihat dari analisis data disetiap siklusnya. Pada siklus I, prosentase aktivitas siswa sebesar $67 \%$ dengan kategori cukup aktif. Pada siklus II, prosentase aktivitas siswa meningkat sehingga mencapai nilai sebesar $73 \%$ dengan kategori cukup aktif. Pada siklus III, prosentase aktivitas siswa meningkat sehingga mencapai nilai sebesar $87 \%$ dengan kategori aktif. (2) Upaya meningkatkan hasil belajar matematika dengan alat peraga batang napier pada materi operasi perkalian telah tercapai. Hal ini ditunjukkan dengan nilai kentutasan klasikal sebelum pembelajaran menggunakan alat peraga batang napier. Ketuntasa klasikal pada siklus I sebesar 40,74\% dengan rata-rata nilai 62,78. Pada siklus II, ketuntasan klasikal yang dicapai siswa sebesar 66,67\% dengan rata-rata nilai 74,26. Pada siklus III, ketuntasan klasikal yang dicapai siswa sebesar 92,59\% dengan rata-rata nilai 87,22. (3) Berdasarkan keterangan di atas dapat di simpulkan bahwa pembelajaran menggunakan alat peraga batang napier dapat meningkatkan aktivitas belajar siswa dan hasil belajar matematika siswa kelas III SDN Tampungrejo Puri Kabupaten Mojokerto.

\section{SARAN}

Berdasarkan hasil penelitian yang telah dilakukan peneliti memberikan saran sebagai berikut: (1) dalam kegiatan pembelajaran guru bisa memanfaatkan alat peraga batang napier sebagai salah satu alternatif dalam menyampaikan mata pelajaran matematika untuk meningkatkan hasil belajar dan aktivitas siswa. (2) diharapkan siswa terus meningkatkan rasa ingin tahu dengan belajar menggunakan alat peraga batang napier. (3) Pada saat mendapat tugas kelompok dan harus dipresentasikan ke depan kelas, siswa harus bertanggung jawab dan percaya diri. (4) Lebih menekankan keaktifan seluruh siswa sebagai upaya meningkatkan hasil belajar matematika siswa dengan penerapan pembelajaran menggunakan alat peraga batang napier.

\section{DAFTAR PUSTAKA}

Arikunto, Suharsimi. 2010. Prosedur Penelitian Suatu Pendekatan Praktik. Jakarta: Rineka Cipta.

Arikunto, Suharsimi. 2011. Dasar-dasar Evaluasi Pendidikan Edisi Revisi. Jakarta: PT. Bumi Aksara.

Fajariyah, Nur dan Defi Triratnawati. 2008. Matematika untuk SD/MI Kelas 3. Jakarta : Pusat Perbukuan.

Heruman. 2008. Model Pembelajaran Matematika. Bandung: PT. Remaja Rosdakarya. 
Undang - Undang Republik Indonesia Nomor: 20 Tahun 2003 tentang Sistem Pendidikan Nasional (SISDIKNAS). Bandung: Fermana. 